\title{
Analisa Kinerja Teknik Reduksi PAPR Metode SLM dan HPA Predistorsi dengan Pemodelan Hammerstein pada Sistem OFDM
}

\author{
Ida Anisah 1, Yoedy Moegiharto' ${ }^{2}$ Mohamad Ridwan'3 ${ }^{3}$ Igatya Hana Idfira ${ }^{4}$ \\ 1, 2, 3, 4 Program Studi Teknik Telekomunikasi, Departemen Teknik Elektro, Politeknik Elektronika Negeri \\ Surabaya; \\ *Corespondence: ida@pens.ac.id;
}

\begin{abstract}
Abstrak: Teknik OFDM mempunyai kelemahan, salah satunya adalah tingginya PAPR yang akan menyebabkan distorsi non-linear pada Power Amplifier (PA), dikarenakan PA membatasi keluaran dengan nilai tertentu yang dapat mengurangi efisiensi daya amplifier. Dalam mengatasi masalah tersebut maka diperlukan teknik reduksi PAPR. Untuk teknik reduksi PAPR efisien yang digunakan adalah Selective Mapping (SLM). Teknik Reduksi PAPR SLM sendiri tidak dapat digunakan untuk memperbaiki daerah non-linear pada Power Amplifier, oleh karena itu diterapkan teknik pemodelan HPA Predistorsi untuk meningkatkan efisiensi dari PA dengan memperluas jangkauan linear dan mencegah sinyal jatuh ke wilayah saturasi PA. Untuk pemodelan HPA yang digunakan yaitu pemodelan Hammerstein. Model Hammerstein ini sederhana namun efektif untuk menggambarkan kinerja PA dan kinerja predistorter non-linear akan berlawanan dengan PA dengan menggunakan efek memori. Hasil kerja dari teknik gabungan tersebut dapat dianalisa berdasakan kurva BER dan kurva CCDF yang dihasilkan. Performansi BER dapat diperbaiki ketika menggunakan teknik reduksi SLM yang dikombinasikan dengan Teknik Predistorsi, dimana pada nilai SNR sebesar $15 \mathrm{~dB}$ sudah mampu mengatasi probabilitas BER. Namun, ketika tanpa Teknik Predistorsi baru bisa mengatasi probabilitas BER pada nilai SNR sebesar $22 \mathrm{~dB}$. Untuk teknik reduksi SLM dan Teknik Predistorsi dengan subblok 16 mampu menghasilkan nilai lebih baik daripada saat menggunakan subblok 4 dan 8 yaitu dapat mencapai probabilitas BER hingga 10-6 dengan nilai SNR $14 \mathrm{~dB}$, dan sudah dapat mengatasi probabilitas BER pada SNR $15 \mathrm{~dB}$. Dengan Teknik Predistorsi ini mampu meningkatkan linearisasi pada PA. Sehingga dapat dibuktikan untuk dapat melewati HPA, sinyal dengan reduksi menggunakan subblok 4 sudah dapat melewati HPA yang mempunyai linearisasi tinggi.
\end{abstract}

Kata Kunci: OFDM; PAPR; Pemodelan Hammerstein, Predistorsi, Selective Mapping;

\section{Pendahuluan}

Saat ini komunikasi menjadi kebutuhan yang sangat penting. Para pengguna jasa telekomunikasi berharap untuk dapat melakukan komunikasi dan pengiriman data dengan jumlah besar yang berlangsung cepat dan berkualitas tinggi dengan teknologi nirkabel. Teknologi nirkabel membutuhkan kemampuan pengiriman data yang berukuran besar dengan kecepatan yang tinggi dan membutuhkan bandwidth yang besar, namun bandwidth yang tersedia hanya terbatas. Oleh karena itu dalam pengiriman data pada sistem komunikasi diterapkan teknik transmisi multi-carrier yaitu Orthogonal Frequency Division Multiplexing (OFDM). Pada system OFDM subcarrier-subcarrier akan di IDFT/IFFT sehingga dapat saling tegak lurus satu sama lain sehingga efisiensi bandwidth dapat terpenuhi. Orthogonal Frequency Division Multiplexing (OFDM) diketahui sangat tahan terhadap kanal multipath dan hemat bandwidth. Dengan harapan, bila terjadi distorsi pada sistem 
komunikasi yang menyebabkan Intersymbol Interference (ISI) atau Intercarrier Interference (ICI) pada penerima masih dapat dipisahkan pada sub kanal dengan menggunakan DFT/FFT.

Di dalam sistem OFDM ini terdapat beberapa kelemahan yaitu salah satunya tingginya nilai Peak Average Power Rasio (PAPR) pada sinyal yang dikirimkan, yang dapat menyebabkan penyebaran spektral yang signifikan dan distorsi in-band ketika sinyal OFDM melewati penguat daya non-linear (PA). Tingginya nilai PAPR ini dapat menurunkan efisiensi daya dari high power amplifier, menyebabkan rentan terhadap distorsi sehingga sinyal yang dikirimkan menjadi nonlinear, dan dapat meningkatkan kompleksitas Analog to Digital (A/D) maupun sebaliknya Digital to Analog (D/A) [1]. Pada penelitian ini digunakan teknik reduksi PAPR Selective Mapping (SLM). Teknik ini mempunyai skema yang sangat fleksibel dan memiliki kinerja efektif dalam pengurangan PAPR tanpa distorsi sinyal [2]. Namun, teknik tersebut hanya berkonsentrasi pada pengurangan PAPR dan tidak mempertimbangkan model non-linear PA.

Teknik Predistorsi dalam hal ini merupakan teknik yang dapat memperluas jangkauan linear dan juga meningkatkan efisiensi dari PA. Dalam Teknik Predistorsi dipelajari untuk membuat kompensasi untuk karakteristik non-linear dari PA [3]. Teknik Predistorsi ini mempunyai karakteristik yang berlawanan dari PA. Untuk Teknik Predistorsi yang digunakan yaitu Teknik Predistorsi dengan pemodelan HPA Hammerstein. Input dari Pemodelan Hammerstein ini berupa non-linear statik dengan output dari PA Hammerstein adalah linear dinamik. Hasil menunjukkan bahwa PA menggunakan model Hammerstein lebih mudah untuk memperkirakan, membutuhkan lebih sedikit parameter untuk mengidentifikasi dan mencapai hasil yang lebih baik ketika pemodelan Hammerstein dapat relatif sederhana [4].

Dalam penelitian ini, peneliti mengusulkan analisa hasil performansi kinerja teknik reduksi SLM yang dikombinasikan dengan Teknik Predistorsi Hammerstein yang dapat ditunjukkan dengan kurva CCDF, kurva AM/AM dan kurva BER yang dihasilkan. Metode teknik reduksi SLM diterapkan untuk mengurangi PAPR sinyal OFDM, yang mencegah sinyal jatuh ke wilayah saturasi PA dan Teknik Predistorsi untuk memperluas jangkauan linear PA, sehingga dapat memperbaiki performansi pada sistem.

\section{Model Sistem}

\subsection{Orthogonal Frequency Division Multiplexing (OFDM)}

Gambar 1 menunjukkan bahwa pada sisi pengirim (transmitter), informasi yaitu $\mathrm{x}(\mathrm{t})$ yang berbentuk serial diubah menjadi data paralel sebelum masuk ke dalam proses modulasi [5].

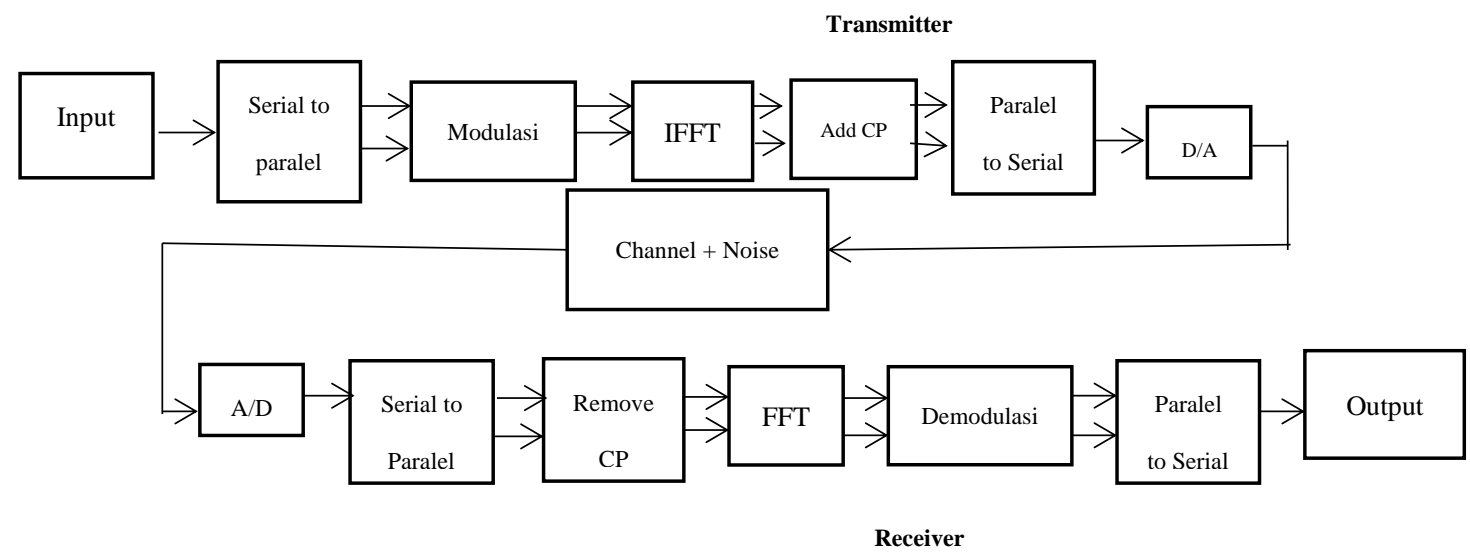

Gambar 1. Blok Diagram Sistem OFDM

Sinyal hasil modulasi tersebut masuk ke dalam IFFT (Inverse Fast Fourier Transform) untuk membuat frekuensi data saling tegak lurus atau orthogonal sehingga didapatkan $\mathrm{x}(\mathrm{n})$ pada persamaan 2.1 berikut : 


$$
x(n)=\sum_{n=0}^{N-1} x(k) \sin \left(\frac{2 \pi k n}{N}\right)-\sum_{n=0}^{N-1} x(k) \cos \left(\frac{2 \pi k n}{N}\right)
$$

Output dari IFFT akan ditambahkan cyclic prefix sebagai pemisah frekuensi pembawa yang saling tumpang tindih. Cyclic Prefix didapatkan dari salinan bagian akhir simbol OFDM yang ditambahkan pada awal simbol. Dengan menggunakan cyclic prefix akan mengurangi ISI (intersymbol interference) dan ICI (inter-carrier interference). Setelah proses penambahan cyclic prefix, data/informasi kemudian diubah lagi ke dalam bentuk serial dan melalui proses konversi dari data digital ke analog sebelum data tersebut dikirimkan melalui udara. Sinyal yang dikirim oleh transmitter berupa sinyal yang saling overlapping sehingga dapat menghemat bandwidth. Pada OFDM kondisi overlapping ini tidak menimbulkan interferensi antar kanal.

Proses pada penerima (receiver) merupakan kebalikan dari proses yang terjadi pada transmitter. Sinyal analog yang baru diterima oleh receiver dikonversi menjadi sinyal digital untuk diproses. Sinyal tersebut diubah dari serial ke parallel. Setelah itu dilakukan pembuangan cyclic prefix dan dilakukan proses FFT. FFT berfungsi sebagai pengurai simbol OFDM yaitu memisahkan antara frekuensi carrier dengan simbol OFDM, sehingga dapat dihasilkan $\mathrm{x}(\mathrm{k})$ yang dapat ditulis pada persamaan 2.2 sebagai berikut. Setelah proses FFT sinyal didemodulasi dan diubah terlebih dahulu dari paralel ke serial, kemudian didapatkan sinyal yang diterima dalam bentuk y(n).

$$
x(k)=\sum_{n=0}^{N-1} x(n) \sin \left(\frac{2 \pi k n}{N}\right)+\sum_{n=0}^{N-1} x(n) \cos \left(\frac{2 \pi k n}{N}\right)
$$

\subsection{Predistorsi}

Jika PA ideal, perbedaan antara input dan output dari PA hanya akan mendapatkan gain yang hanya perkalian dengan nomor skalar. Terlebih lagi jika PA ideal, gain dari penguat daya akan sama untuk semua tingkat input, namun karena mendapatkan kompresi yang juga menyebabkan nonlinearitas; gain tidak konstan untuk semua level input. Untuk mengkompensasi non-linearitas dan efek memori dari PA, algoritma predistorsi digital diperlukan. Predistorsi adalah teknologi linearisasi PA yang efektif [6][7]. Model predistorsi memiliki karakteristik terbalik dari PA. Namun cascade predistorter dan PA membuat output PA menjadi linear sehubungan dengan input predistorter, seperti yang ditunjukkan pada Gambar 2. Sementara itu kita dapat melihat bahwa untuk sinyal besar, hasil keluarannya dibatasi pada level tertentu. Meskipun predistorter diterapkan sebelum PA, output linear daerah saturasi kecil. Ketika berada pada daerah saturasi, predistoter tidak akan bekerja [8].

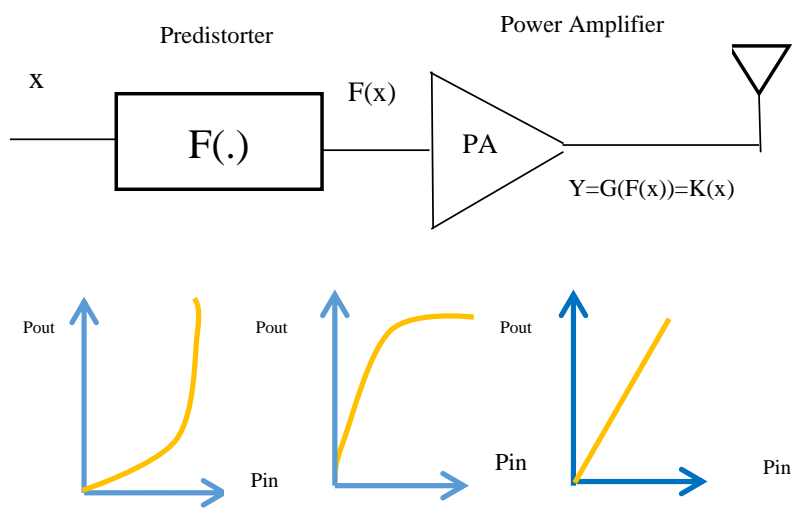

Gambar 2. Dasar Linearisasi Predistorsi 


\subsection{Model Hammerstein}

Model Hammerstein terdiri dari sistem non-linear tanpa memori (memoryless) diikuti oleh sistem linear time-invariant (LTI). Dimana Masukan struktur Hammerstein, $\mathrm{x}(\mathrm{k})$ adalah input model linear dan $\mathrm{y}(\mathrm{k})$ adalah model linear yang menjadi output struktur Hammerstein. Pemodelan Hammerstein dapat digambarkan pada Gambar 3 [9] :

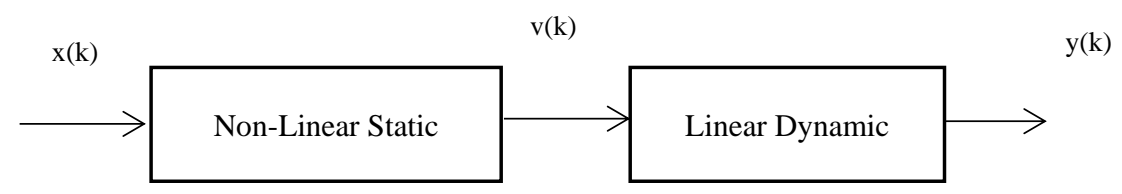

$$
\begin{array}{r}
\text { Gambar 3. Pemodelan Hammerstein } \\
v(k)=\sum_{p=0}^{p} \gamma_{p} \cdot x(k) \cdot|x(k)|^{p} \\
y(k)=\sum_{d=1}^{D} a_{d} \cdot y(k-d)+\sum_{n=0}^{N} \beta_{n} \cdot v(k-n)
\end{array}
$$

Dengan $\mathrm{y}(\mathrm{k})$ keluaran PA atau predistorter dan $\mathrm{v}(\mathrm{k})$ keluaran blok memoryless non-linear, $\mathrm{p}$ adalah urutan dari polinomial memoryless, sementara $\mathrm{n}$ dan $\mathrm{d}$ adalah urutan pole / zero umum masingmasing. Dengan menggabungkan persamaan 2.3 dan 2.4 maka diperoleh persamaan :

$$
y(k)=\sum_{d=1}^{D} a_{d} \cdot y(k-d)+\sum_{n=0}^{N} \beta_{n} \cdot \sum_{p=0}^{p} \gamma_{p} \cdot x(k-n) \cdot|x(k-n)|^{p}
$$

\subsection{Teknik Gabungan Reduksi PAPR SLM dan Model Hammerstein}

Blok diagram pada Gambar 2 merupakan sistem yang dirancang pada penelitian ini. Pertama, data dibangkitkan secara acak sejumlah simbol input yang ditentukan berbentuk serial (a). Data input yang dibangkitkan secara acak selanjutnya akan dimodulasi menggunakan modulasi QPSK (b). Setelah itu, hasil dari modulasi akan diteruskan untuk direduksi menggunakan teknik reduksi Selective Mapping (c). Pada SLM, blok data input disalin menjadi U data blok yang disusun secara paralel. Kemudian output sinyal setiap blok, akan diolah menggunakan proses IFFT yaitu mengubah sinyal dari domain frekuensi menjadi domain waktu.

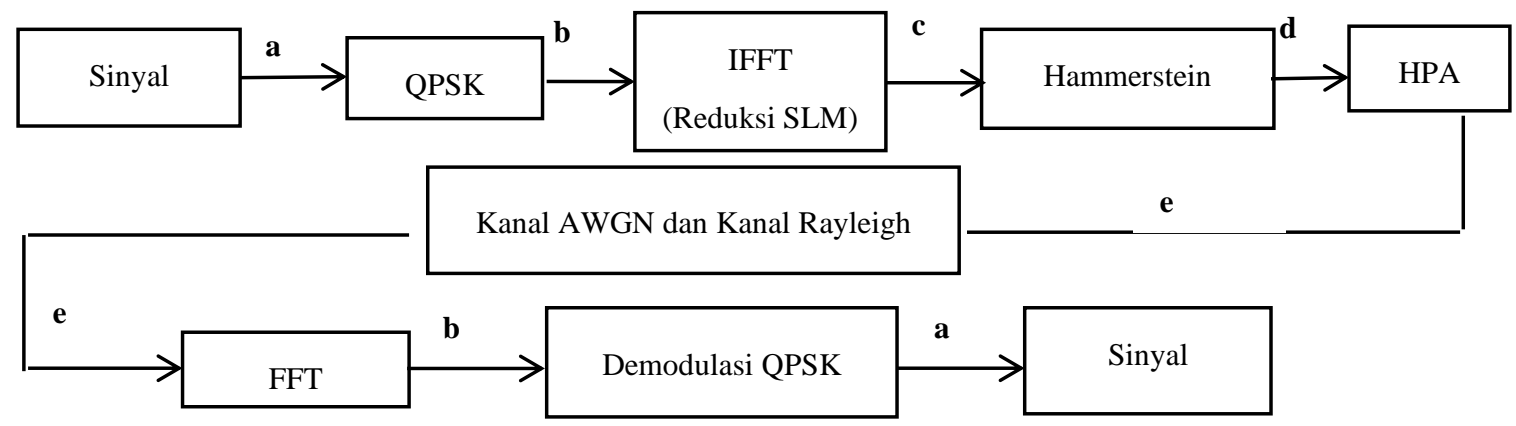

Gambar 2 Diagram Teknik Gabungan Reduksi SLM dan Hammerstein Model 
Setelah itu sinyal yang telah di IFFT akan dipilih output yang memiliki nilai PAPR terendah. Hasil nilai PAPR terendah dipilih untuk ditransmisikan dan digunakan sebagai input dari Teknik Predistorsi Hammerstein untuk memperluas jangkauan linear dari PA (d). Teknik Predistorsi Hammerstein ini digunakan untuk menghindari terjadinya distorsi non-linear, sehingga saat masuk menuju HPA sinyal akan lebih sedikit distorsinya (e). Kemudian dikirimkan melalui kanal ideal AWGN dan Rayleigh.

Pada sisi penerima dilakukan konversi dari serial ke paralel, selanjutnya diubah ke domain waktu dengan FFT (b), dan dilakukan konversi lagi dari paralel ke serial. Terakhir dilakukan proses demodulasi QPSK (a). Sehingga didapatkan bentuk sinyal OFDM sama pada saat dikirim. Selanjutnya akan dilakukan pengeplotan kurva CCDF untuk mengetahui kinerja dari teknik reduksi PAPR SLM dan akan dilakukan pengeplotan kurva BER untuk mengetahui perbandingan kinerja sistem dengan menggunakan Teknik Predistorsi dan ketika tanpa menggunakan Teknik Predistorsi.

\section{Hasil}

\subsection{Hasil Simulasi dan Analisa Sistem OFDM dengan Teknik Reduksi SLM dan Predistorsi Hammerstein}

Pada pengujian ini dilakukan plot kurva BER antara sistem OFDM dengan teknik reduksi yang mempunyai subblok berbeda yaitu subblok 4, subblok 8, dan subblok 16 . Untuk warna hijau yaitu kurva BER untuk teknik reduksi SLM dan predistorsi subblok 4, untuk kurva berwarna biru muda yaitu kurva BER untuk teknik reduksi subblok 8, untuk kurva berwarna biru tua yaitu kurva BER untuk teknik reduksi subblok 16. Jumlah bit yang dibangkitkan adalah 1.024 .000 bit, untuk modulasi yang digunakan QPSK, dan subcarrier yang digunakan berjumlah 512. Untuk kurva BER SLM dan Teknik Predistorsi beda subblok dapat ditunjukkan pada Gambar 3.1.

Pada Tabel 1 dapat dianalisa, saat ketiga kondisi pada nilai SNR $6 \mathrm{~dB}$, memiliki probabilitas BER 10-2. Pada saat SNR bernilai $13 \mathrm{~dB}$, probabilitas BER sudah mencapai 10-5. Pada saat SNR $14 \mathrm{~dB}$ untuk subblok 4, subblok 8, dan subblok 16 probabilitas BER sudah mencapai 10-6. Namun, pada subblok 8 dan subblok 16 pada saat SNR 15 dB sudah dapat mengatasi probabilitas BER. Sedangkan, untuk subblok 4 baru bisa mengatasi probabilitas BER saat berada pada SNR $16 \mathrm{~dB}$ dengan data yang dikirim sebanyak 1.024 .000 bit.

Dari penggunaan 3 subblok yang berbeda hasilnya tidak mengalami perbedaan yang signifikan. Tetapi untuk nilai probabilitas BER terbaik terdapat pada subblok 16 jika dibandingkan dengan subblok 4 dan subblok 8 . Untuk nilai BER terhadap SNR dengan 3 subblok yang berbeda dapat dilihat pada Tabel 1. 


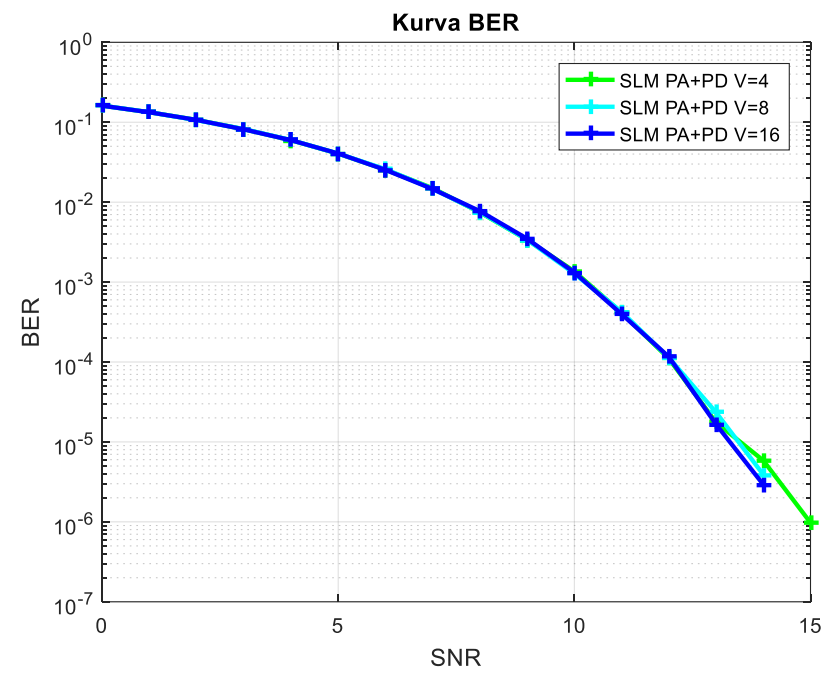

Gambar 3. Kurva BER dengan Subblok Berbeda

Tabel 1. Nilai BER terhadap SNR hasil simulasi kinerja teknik reduksi PAPR SLM dengan subblok yang berbeda.

\begin{tabular}{cccc}
\hline \multirow{2}{*}{ SNR } & \multicolumn{3}{c}{ Bit Error Rate (BER) } \\
\cline { 2 - 4 }$(\mathrm{dB})$ & Subblok V=4 & Subblok V=8 & Subblok V=16 \\
\hline $\mathbf{6}$ & $2 \times 10^{-2}$ & $2 \times 10^{-2}$ & $2 \times 10^{-2}$ \\
\hline $\mathbf{7}$ & $1 \times 10^{-2}$ & $1 \times 10^{-2}$ & $1 \times 10^{-2}$ \\
\hline $\mathbf{8}$ & $7 \times 10^{-3}$ & $7 \times 10^{-3}$ & $7 \times 10^{-3}$ \\
\hline $\mathbf{9}$ & $3 \times 10^{-3}$ & $3 \times 10^{-3}$ & $3 \times 10^{-3}$ \\
\hline $\mathbf{1 0}$ & $1 \times 10^{-3}$ & $1 \times 10^{-3}$ & $1 \times 10^{-3}$ \\
\hline $\mathbf{1 1}$ & $4 \times 10^{-4}$ & $4 \times 10^{-4}$ & $4 \times 10^{-4}$ \\
\hline $\mathbf{1 2}$ & $1 \times 10^{-4}$ & $1 \times 10^{-4}$ & $1 \times 10^{-4}$ \\
\hline $\mathbf{1 3}$ & $1 \times 10^{-5}$ & $2 \times 10^{-5}$ & $1 \times 10^{-5}$ \\
\hline $\mathbf{1 4}$ & $6 \times 10^{-6}$ & $4 \times 10^{-6}$ & $3 \times 10^{-6}$ \\
\hline $\mathbf{1 5}$ & $1 \times 10^{-6}$ & - & - \\
\hline
\end{tabular}

\subsection{Hasil Simulasi dan Analisa Teknik Reduksi PAPR SLM dengan Teknik Predistorsi dan Tanpa Teknik Predistorsi Menggunakan Subcarrier 512 dengan Kurva BER}

Pada pengujian ini dilakukan pada sistem OFDM menggunakan teknik reduksi PAPR SLM dengan Teknik Predistorsi pemodelan HPA Hammersrtein dan tanpa Teknik Predistorsi pemodelan Hammerstein yang ditampilkan dengan menggunakan kurva BER. Dalam pengujian menggunakan jumlah subcarrier 512. Subblok yang digunakan berjumlah 4 dengan data yang dibangkitkan 1.024.000 bit. Untuk hasil kurva BER ditunjukkan dengan Teknik Predistorsi dan tanpa Teknik Predistorsi dengan subcarrier 512 dapat ditunjukkan pada Gambar 3.2.

Dari Tabel 3.2 diatas dapat dianalisa bahwa nilai BER yang dihasilkan untuk Teknik gabungan Reduksi SLM dengan Teknik Predistorsi Hammerstein dan tanpa menggunakan Teknik Predistorsi 


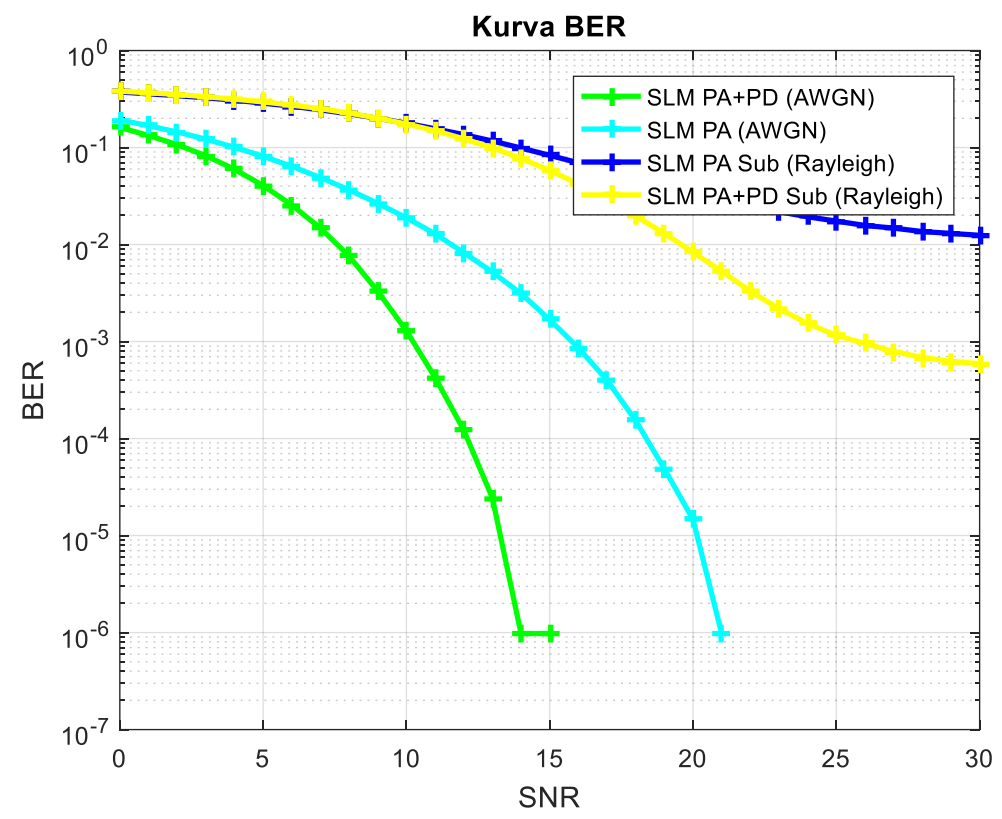

Gambar 4. Kurva BER dengan Teknik Predistorsi dan Tanpa Teknik Predistorsi dengan Subcarrier 512

Tabel 2. Nilai BER Terhadap SNR dengan Menggunakan Teknik Predistorsi dan Tanpa Teknik Predistorsi dengan Subcarrier 512

\begin{tabular}{ccccc}
\hline SNR & \multicolumn{4}{c}{ Bit Error Rate (BER) } \\
\cline { 2 - 5 } (dB) & Subcarrier 512 & Subcarrier & Subcarrier & Subcarrier \\
& PA+PD & 512 & 512 & 512 PA+PD \\
& AWGN & PA AWGN & PA Rayleigh \\
\hline $\mathbf{6}$ & $2 \times 10^{-2}$ & $6 \times 10^{-2}$ & $2 \times 10^{-1}$ & $2 \times 10^{-1}$ \\
\hline $\mathbf{7}$ & $1 \times 10^{-2}$ & $5 \times 10^{-2}$ & $2 \times 10^{-1}$ & $2 \times 10^{-1}$ \\
\hline $\mathbf{8}$ & $7 \times 10^{-3}$ & $3 \times 10^{-2}$ & $2 \times 10^{-1}$ & $2 \times 10^{-1}$ \\
\hline $\mathbf{9}$ & $3 \times 10^{-3}$ & $2 \times 10^{-2}$ & $1 \times 10^{-1}$ & $2 \times 10^{-1}$ \\
\hline $\mathbf{1 0}$ & $1 \times 10^{-3}$ & $2 \times 10^{-2}$ & $1 \times 10^{-1}$ & $1 \times 10^{-1}$ \\
\hline $\mathbf{1 1}$ & $4 \times 10^{-4}$ & $1 \times 10^{-2}$ & $1 \times 10^{-1}$ & $1 \times 10^{-1}$ \\
\hline $\mathbf{1 2}$ & $1 \times 10^{-4}$ & $8 \times 10^{-3}$ & $1 \times 10^{-1}$ & $1 \times 10^{-1}$ \\
\hline $\mathbf{1 3}$ & $2 \times 10^{-5}$ & $5 \times 10^{-5}$ & $9 \times 10^{-2}$ & $1 \times 10^{-1}$ \\
\hline $\mathbf{1 4}$ & $10 \times 10^{-7}$ & $3 \times 10^{-3}$ & $7 \times 10^{-2}$ & $10 \times 10^{-2}$ \\
\hline $\mathbf{1 5}$ & - & $1 \times 10^{-3}$ & $6 \times 10^{-2}$ & $8 \times 10^{-2}$ \\
\hline
\end{tabular}

Hammersein. Saat nilai SNR $6 \mathrm{~dB}$, nilai probabilitas BER dari sistem yang menggunakan Teknik Predistorsi dan tidak menggunakan Teknik Predistorsi melalui kanal AWGN sama yaitu $10^{-2}$. Saat nilai SNR bertambah, sistem yang menggunakan Teknik Predistorsi Hammerstein mengalami perbaikan nilai probabilitas BER lebih baik. Ketika dengan menggunakan Predistorsi melalui kanal AWGN pada SNR bernilai $14 \mathrm{~dB}$ sudah mempunyai nilai probabilitas BER sebesar $10^{-7}$, sehingga pada nilai SNR $15 \mathrm{~dB}$ sudah dapat mengatasi nilai probabilitas BER dengan jumlah data input 
1.024.000 bit. Ketika tanpa menggunakan Teknik Predistorsi baru dapat mengatasi probabilitas BER sebesar 10-7 pada nilai SNR $21 \mathrm{~dB}$ dengan data input 1.024 .000 bit. Dapat dianalisa bahwa Teknik Predistorsi dapat memperbaiki kinerja BER dengan baik. Untuk hasil pengamatan dari kurva BER dapat ditampilkan pada Tabel 2.

Untuk teknik gabungan Reduksi SLM dengan Teknik Predistorsi Hammerstein dan tanpa menggunakan Teknik Predistorsi Hammersein melalui kanal Rayleigh. Saat data dikirim melalui kanal Rayleigh sistem mempunyai nilai probabilitas BER lebih besar dari pada saat data dikirim melalui kanal AWGN. Tidak seperti saat melalui kanal AWGN, pada kurva BER dengan Teknik Predistorsi melalui kanal Rayleigh pada SNR 30 dB bisa mengatasi probabilitas error sebesar 10-4, sedangkan saat tanpa Teknik Predistorsi melalui kanal Rayleigh hanya mampu mengatasi probabilitas error sebesar 10-2. Dapat dianalisa bahwa saat menggunakan kanal AWGN mampu mengatasi nilai BER lebih baik daripada saat menggunakan kanal Rayleigh. Walaupun menggunakan kanal Rayleigh, sistem dengan menggunakan Teknik Predistorsi tetap menghasilkan kinerja lebih baik daripada sistem tanpa menggunakan Teknik Predistorsi.

\subsection{Hasil Simulasi dan Analisa Kurva Linearisasi AM/AM pada Teknik Predistorsi Pemodelan HPA Hammerstein}

Pada pengujian ini dilakukan pada kurva linearisasi AM/AM yang dihasilkan dari teknik reduksi SLM dan Teknik Predistorsi pemodelan HPA Hammerstein. Pada kurva linearisasi ini menunjukkan, jika sebelum dilakukan Teknik Predistorsi sebuah PA mempunyai linearitas yang kecil, sehingga setelah dilakukannya Teknik Predistorsi ini, PA menghasilkan linearitas yang lebih besar, sehingga tidak terjadi distorsi non-linear yang akan terjadi di HPA dan juga dengan Teknik Predistorsi ini dapat meningkatkan daerah linear pada amplifier. Pada kurva berwarna biru menunjukkan kurva setelah melewati PA, kemudian pada kurva berwarna merah muda menunjukkan kurva predistorsi yang mempunyai karakteristik berlawan dengan PA, dan kurva berwarna hijau menunjukkan kurva linearitas setelah dilakukan Teknik Predistorsi. Ketiga kurva tersebut dapat digabungkan menjadi kurva AM/AM seperti pada Gambar 3.

Pada pengujian ini dapat dianalisa bahwa berdasarkan hasil kurva AM/AM dari teknik reduksi dan Teknik Predistorsi pemodelan Hammerstein menghasilkan PA yang linear. Dimana, dapat diketahui bahwa daya output maksimumnya yaitu sebesar 0,289 watt. Untuk keluaran tertinggi pada amplitudo sinyal setelah dilakukannya reduksi yaitu sebesar 0,17 V, yang ditunjukkan pada Gambar 4. Sehingga apabila dikonversikan ke amplitudo dalam volt dapat dituliskan :

$$
\text { Pout }=\frac{\text { Vout }^{2}}{R}
$$

dengan R dianggap 1, maka Vout $=\sqrt{0,0289}$ watt, dan Vout $=0,17 \mathrm{~V}$. Dapat dianalisa bahwa sinyal dengan hasil teknik reduksi Subblok 4 yang sebelumnya tidak dapat melewati batas HPA kelas AB ZHL100+6W karena masih memiliki PAPR yang tinggi yang melebihi batas HPA, dengan dilakukannya Teknik Predistorsi sinyal hasil reduksi dengan Subblok 4 ini sudah mampu digunakan untuk melewati HPA dengan tidak merusak sinyal yang melewatinya karena HPA masih mampu bekerja secara linear dengan nilai keluaran tertinggi amplitudo sinyal yang dimiliki sinyal hasil reduksi Subblok 4. 


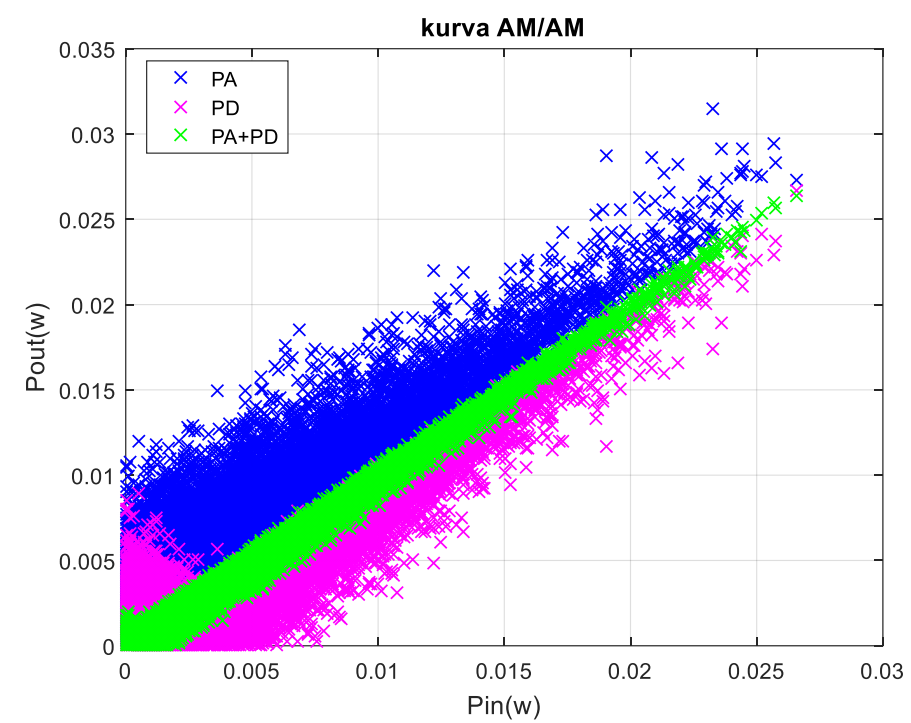

Gambar 3 Kurva AM/AM

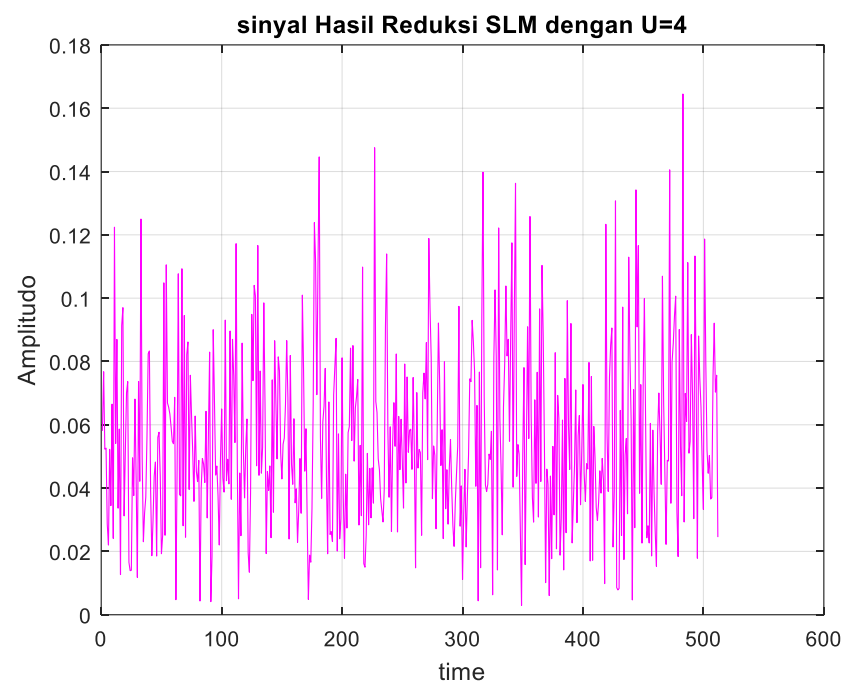

Gambar 4 Sinyal Hasil Reduksi Subblok 4

Dengan menggunakan sinyal hasil reduksi pada Subblok 4 sudah dapat digunakan untuk melewati HPA tanpa harus menggunakan subblok yang lebih banyak lagi, karena dengan semakin banyaknya jumlah subblok yang digunakan dapat meningkatkan komputasi sistem dan membutuhkan waktu yang lama dalam memprosesnya.

\section{Kesimpulan}

Dari hasil pengujian sistem dan analisa pada software MATLAB, dapat simpulkan bahwa Pada teknik reduksi SLM yang dikombinasikan dengan Teknik Predistorsi pemodelan HPA Hammerstein mempunyai probabilitas BER yang paling baik dibanding saat menggunakan subblok 4 dan 8 , dimana saat menggunakan subblok 8 dimana pada SNR $14 \mathrm{~dB}$ sudah mampu mengatasi probabilitas sebesar $10^{-6}$. Pada teknik reduksi SLM yang dikombinasikan dengan Teknik Predistorsi pemodelan HPA menghasilkan performansi BER yang lebih baik daripada saat tidak menggunakan Teknik Predistorsi pemodelan HPA, dimana nilai BER yang didapat saat menggunakan Teknik Predistorsi mampu mengatasi probabilitas BER sebesar $10^{-7}$ pada SNR $15 \mathrm{~dB}$, ketika tidak menggunakan Teknik Predistorsi baru bisa mengatasi probabilitas BER $10^{-7}$ pada SNR $21 \mathrm{~dB}$. Dengan Teknik 
Predistorsi ini mampu meningkatkan linearitas pada PA, dimana sebelumnya sinyal dengan reduksi menggunakan subblok 4 tidak dapat melewati HPA, ketika dilakukan Teknik Predistorsi linearitas HPA bertambah dan sinyal dengan teknik reduksi subblok 4 bisa melewati HPA

\section{Referensi}

1. Agustana Prasetia M., Rina Puji Astuti, Nachwan Mufti, "Reduksi PAPR Pada Sinyal OFDM Dengan Selective Mapping Menggunakan Turbo Coding", Tugas Akhir Universitas Telkom Bandung, 2008.

2. S. H. Han and J. H. Lee, "An Overview of peak-to-average power ratio reduction techniques for multicarrier transmission," IEEE Wireless Commun., vol. 12, pp. 56-65, Apr. 2005.

3. Gang Tong, Qiang Wang, Guixin Wang. "A Performance Controllable PA linearization Scheme of Joint PAPR Reduction and Predistortion". IEEE. Wireless Technology Innovation Institute, Beijing University of Posts and Telecommunications. Beijing. China. 2012.

4. P.L. Gilabert, G. Montoro and E. Bertran. "On the Wiener and Hammerstein Models for Power Amplifier Predistortion". IEEE. Department of Signal Theory and Communications. Universitat Politècnica de Catalunya (UPC). Spain. 2005.

5. F. Ouyang. "Orthogonal Frequency Division Multiplexing (OFDM)". Digital Communication for Practicing Engineers. John B. Anderson, Ed. Canada: John Wiley \& Sons, 2020.

6. G. Montoro, P. L. Gilabert, E. Bertran, "A New Digital Predictive Predistorter for Behavioral Power Amplifier Linearization", IEEE Microwave and Wireless Components Letters, Vol. 17, No. 6, June 2007.

7. Jessica Chani-Cahuana, "Digital Predistortion for the Linearization of Power Amplifiers", Communication Systems and Information Theory Group Department of Signals and Systems Chalmers University of Technology G"oteborg, Sweden, 2015.

8. Emanuele Tolomei. "Design and implementation of a software predistorter for amplifier linearization in OFDM-based SDR systems". Department of Information Engineering. Anno Accademico: 2016.

9. A. Rahati Belabad, E. Iranpour and S. Sharifian "FPGA Implementation of a Hammerstein Based Digital Predistorter for Linearizing RF Power Amplifiers with Memory Effects", Vol. 47, No. 2, 2015. 